\title{
Crime, Politics, and Punishment: Criminological Research for Political Sociologists
}

Thomas D. Stucky

\begin{abstract}
As a sociologist studying the intersection of crime, punishment and politics, it is often surprising to me how many aspects of political sociology and the study of crime and punishment overlap, and yet, there is often limited cross-fertilization of the two fields. For the sake of brevity in this discussion, I refer to those who study crime, deviance, law, criminal justice, and punishment as criminologists. My goal is to provide an extremely brief "primer" on criminology for political sociologists, in the hopes that a short reading of some issues and research in criminology may stimulate additional theorizing and research, as has so often happened when I have read political sociological work. To do this, I begin with a brief discussion of overlaps in political sociological and criminological perspectives. Following this, I highlight some examples of criminological research which incorporates politics, and would likely interest political sociologists, Then, I highlight a hot button issue in criminology—sex offenses - and suggest some ways that political sociologists could examine recent legislation on sex offenders, and conclude with brief discussions of a few additional areas of overlap for the two disciplines.
\end{abstract}

This is the author's manuscript of the article published in final edited form as:

Stucky, T. D. (2013). Crime, Politics, and Punishment: Criminological Research for Political Sociologists. Sociology Compass, 7(7), 561-572. http:/dx.doi.org/10.1111/soc4.12048 


\section{Introduction}

As a sociologist studying the intersection of crime, punishment and politics, it sometimes strikes me as odd how infrequently various disciplines (or even sub-disciplines within a field) seem to be able to capitalize on the insights of others, even when the topics they study overlap tremendously. For example, social psychologists trained in sociology departments often study very different things (or the same things in very different ways) than those trained in psychology departments, despite having seemingly identical fields. So too, it is often surprising to me how many aspects of political sociology and the study of crime and punishment overlap, and yet, there is often limited cross-fertilization of the two fields. For the sake of brevity in this discussion, I refer to those who study crime, deviance, law, criminal justice, and punishment as criminologists, recognizing that individuals who study these topics may have been trained in sociology, political science, psychology, economics, law and society, criminal justice or other disciplines.

Criminology is concerned with the development of rules to prevent or control certain undesirable behaviors and coordinated responses by the state to those who engage in such acts. Political sociology is concerned with how politics shapes society and how society shapes politics. Political sociologists generally focus on four key concepts: power, state, hegemony, and struggle (Neuman 2005), with perhaps the most central being power (see Dobratz, Waldner, and Buzzelll 2012). One key question for political sociologists is..."which individuals and groups in society possess the capacity to pursue their interests, and how is this power exercised and institutionalised (Faulks 2000:1)?” Although power is complex and multi-dimensional, one dimension is coercion or force, and certainly a central concern for criminologists is force (both illegal and legal). Additionally, Piven and Cloward (2012) note that one way to exercise power is through rule-making. Thus, a central concern for political sociologists and criminologists is to understand the forces that lead to certain rules being created, the behaviors these rules sanction, and when these rules can be enforced on others. Because so much of modern power, politics, and rule-making (and enforcement of laws) involves the state, perhaps not surprisingly, many political sociologists and criminologists focus substantial attention on the state, and how societal processes shape the state and vice versa. Thus, there are some natural areas of overlap in both the subject matter and approaches of the two disciplines, which I highlight more specifically with the discussion below.

My goal is to provide a brief "primer" on criminology for political sociologists, in the hopes that a short reading of some ways politics has been discussed in criminology may stimulate additional theorizing and research, as has so often happened when I have read political sociological work. To do this, I begin with a review of some overlaps among political sociological and criminological theories. Following this, I highlight some examples of criminological research likely to interest political sociologists. Then, I discuss a recent hot button topic in criminologylegislation on sex offenders - and pose a few suggestions for research on this issue by political sociologists. I conclude with a brief discussion of some additional areas of overlap between criminology and political sociology_protests, the "penal-welfare complex", and policing. 


\section{Theoretical approaches in political sociology and criminology}

When attempting to understand a research field, one good place to begin is with the theories or perspectives it employs. As this brief discussion will show, there is substantial overlap in the theoretical orientations or perspectives of political sociology and criminology. One perspective in political sociology is the pluralist perspective, which maintains that public policies would generally flow from the desires of the public in a democracy (see Fording 2001; Hicks and Misra 1993). Thus, the development of a new welfare program would be the result of the responsiveness of elected officials to the "will of the people." In criminology, this roughly corresponds to what are often called 'consensus' approaches which view criminal laws as reflecting agreement within a society about which behaviors should be considered taboo (e.g. Merton 1968). Although very popular in the 1950s and early 1960s, the influence of pluralist and consensus perspectives waned in both fields, starting in the late 1960s, with the rise of conflict perspectives.

Despite substantial differences across conflict theories, all agree that power is not equally distributed in society and that public policies do not reflect widespread public agreement. In addition, policies generally benefit some segments of society more than others. There are several strains of conflict theories that have been used in both political sociology and in criminology, often deriving from similar sources. Perhaps the most popular conflict theory traces its roots to the writings of Karl Marx. Although Marx had written his major works during the social upheaval of the Industrial Revolution, his focus on class conflict struck a chord in the 1960s with those dissatisfied with consensus/pluralist perspectives. Marx himself wrote little about crime so much of the theorizing in criminology had to extrapolate from his more general theory to generate predictions about crime and punishment (Quinney 1977; Rusche and Kirschheimer 1968[1939]; Spitzer 1975; Turk 1969). Neo-Marxist theorizing initially developed what came to be known as instrumental Marxism. Instrumental Marxists believed that public policies overtly supported the interests of capitalists, and much of these discussions focused on how the law can used as a tool for controlling the poor. For example, Spitzer (1975) argued that capitalism required large pools of workers that in times of economic downturns could become unemployed and potentially dangerous. Criminal laws were used as a tool to control individuals that Spitzer called "social dynamite" because they could band together to overthrow the system if control were not maintained. Using a more nuanced approach, structural Marxists argued that the laws did not consciously support capitalists but were designed to maintain the overall capitalist system. So, for example, welfare programs might not directly benefit capitalists but they reduce the likelihood of social unrest and therefore help maintain the stability of the overall capitalist system. In the 1970s and 1980s a large body of Neo-Marxist criminological literature developed (some examples are mentioned below).

Although social conflict was primarily economic for Neo-Marxist theories, other conflict theories focused on political power (Chambliss 1999), or racial and ethnic cleavages (Beckett and Sasson 2000; Blalock 1967; Blauner 1972; Bonacich 1972; Horowitz 1985). "Racial threat" theories have been widely employed in crime and punishment research (see Eitle, D'Alessio, and Stolzenberg 2002 for a review). One indisputable fact is that African Americans are disproportionately represented among those arrested and convicted of crimes. Racial threat arguments purport that the explanation lies in the fact that racial and ethnic minorities, especially 
African Americans are seen as a threat to the interests of the racial majority. Thus, criminal laws and selective enforcement of them represent a tool of social control to ensure continued dominance of the white majority. A small sampling of research employing racial threat arguments in criminological includes: D’Alessio, and Stolzenberg (2003); Jackson (1986, 1989), Liska (1992), Olzak (1990, 1992), Ousey and Lee (2008), Parker (2008); Parker, Stults, and Rice (2005).

Another theoretical tradition that has long been central to crime and punishment research is rational choice (sometimes called deterrence) (see Clarke and Cornish 1985 or Nagin 1998 for overviews). In criminological theorizing, the earliest rational choice arguments were developed in the $18^{\text {th }}$ Century by Cesare Beccaria (1996[1764]). Beccaria argued that crime is sometimes easier than legitimate activity and to prevent crime, the pains of punishments must exceed the pleasures/gain associated with crime. Thus, punishments that are more swift, certain, and severe are most likely to prevent crime. Despite, the intuitive appeal of this argument, there is limited evidence that changing criminal penalties influences potential offenders' behavior. The best evidence suggests that certainty of punishment is more important than severity (see Kubrin, Stucky, and Krohn 2009, chapter 2). The major instrument of law enforcement is the police, and Nagin (1998) concludes that some activities of the police appear to produce "deterrent-like" effects but most research does not suggest that simply having more police will reduce crime (but see Levitt 1997).

"Statist" theories have become increasingly popular in political sociology (see Evans, Rueschemeyer, and Skocpol 1984) and have begun to be applied on a limited basis in criminology. From this perspective, public policies are not simply a reflection of public sentiment as the consensus/pluralists argue, nor are they mainly reflections of the interests of the economically, politically or racially powerful as conflict theorists argue. Statist theories recognize that governmental actors have their own interests that are quite unrelated to the needs of the public or the powerful. So, for example, in democratic governments, public policy will be shaped by public opinion and the interests of the powerful but also by the contours of the political system. Because the creation and enforcement of the law are inherently state action and state actors have their own interests, one must understand the dynamics of these interests, how the political system shapes the relationship between the interests of those in government and outside forces to produce policy. For example, Stucky, Heimer, and Lang (2007) argued that variation in corrections spending at the state level is likely driven by threats to public order (real or perceived) but also political considerations for the elected officials who must always be aware of how their policies are likely to influence their chances of re-election.

Finally, a variety of other approaches have been employed in both political sociology and criminology. For discussions of feminist criminology see Daly and Chesney-Lind (1988) and Balfour (2006). For discussions of post-structuralist discourse theories, such as Foucault, see Garland (1990). One theory of crime that incorporates both feminism and Neo-Marxist concepts is power control theory (Hagan, Gillis, and Simpson 1985, 1990). According to the theory, one's class position determines the style of parenting one is likely to engage in and different parenting styles will lead to different levels and types of social control for boys and girls. Sims-Blackwell 
(2000) found some confirmation for the theory in that girls raised in paternalistic families fear legal sanctions more than boys.

It may be a bit of an oversimplification to say that the bulk of theory in both criminology and political sociology descends from Durkheim, Marx, and Weber or reactions to them, but not much of one. In the next section, I briefly discuss some criminological research topics that have strong overlap with political sociology or criminological research questions that have employed political concepts, beginning with research on punishment, followed by research on crime and other criminal justice topics. These examples are not meant to be a complete listing but are meant to illustrate overlaps across political sociology and criminology, and stimulate exploration of new literatures or examination of important issues from a different perspective.

\section{Politics and punishment}

As noted above, two central concerns for political sociologists are power and the state. One of the most explicit and impactful exercises of state power is punishing criminals. Although a central focus for criminologists is examination of punishment for individual crimes, many have also studied societal trends in punishment practices. Early research on punishment trends often focused on how economic forces shaped punishment practices. In particular, Neo-Marxist researchers hypothesized that increases in labor surplus would be associated with increases in punishment, resulting in extensive research examining the link between unemployment and imprisonment (see Chiricos and Delone 1992 for a review). Because early Neo-Marxists saw the state as a tool of capitalists, early work did not focus much on politics, but Jacobs and Carmichael (2001) and Stucky, Heimer, and Lang (2005) consider institutional politics more fully. For example, Stucky et al. (2005) found that competition between political parties was associated with variation in state prison populations across the fifty states and over time. Specifically, prison admissions were higher when the Republican composition of the state legislature was higher and this effect grew stronger as inter-party competition increased.

The virtual explosion of incarceration in the United States that began in the 1970s has led to a substantial research effort to explain the "punitive turn". The role of politics in this phenomenon is highlighted in Beckett (1997), Garland (2001), Gottschalk (2006) and Simon (2007), to name a few. For example, Beckett (1997) examines how politicians use law and order issues to gain political advantage and enhance their likelihood of election by enacting policies that make them appear "tough on crime”. More recently, Barker (2009) compares variation in the developing penal regimes of three states (California, New York, and Washington). Noting that her work is informed by Skocpol and Putnam (p.9), Barker examines "political structures" and "collective agency". She argues that variation on these dimensions across the three states helps to explain their very different responses to similar policy situations (namely dramatic increases in crime). Similarly, Campbell (2011), using archival materials, conducts a case-study of the emergence of "law and order" politics in Texas. And, in an intriguing book, Miller (2008) argues that the federalist structure of the government in the United States also plays an important role in determining who has a voice in crime policy through channeling the ways various group interests are represented at the national, state, and local level. The federalization of crime control as a policy issue means that policy discussions are far removed from those most affected by crime 
and punishment (namely the urban, poor, and minorities). In addition, state and national policy responses are constrained in ways that local government responses might not be. This discussion of group interests, issue framing, and policy in the context of crime control is an excellent example of the kind of nuanced theorizing that can occur when a central policy issue-crime control-is confronted from a political sociological perspective. Finally, Schoenfeld (2010) examines how litigation designed to improve prison conditions (and ultimately reduce incarceration), produces the paradoxical result of dramatic prison expansion. This analysis shows that sometimes even "successful" efforts to force the state to act in certain ways (i.e. winning lawsuits to force improvements in prison conditions) may have large-scale unintended consequences.

Efforts to understand what some call the "prison boom" or "mass incarceration" are now widespread in criminological research and, as is clear from the few examples discussed here, many studies examine this phenomenon in ways familiar to political sociologists. What is less well understood is the issue of what to do with all these prisoners once they return to society or "reentry". ${ }^{1}$ Because most prisoners return to society, reentry has become a critical issue in criminology. Understanding how state and local politics influences reentry policies could also be a fruitful avenue for political sociological research, especially given the enormous economic impact of these increasing populations of ex-offenders.

One additional commonality between political sociology and criminology is an expanding interest in the role of culture. Culture has become a central concern in political sociology (see Nash 2000, chapter 1), and culture is increasingly becoming a focus in in criminological research. For some interesting reading on culture in criminology, I recommend Simon's (2007) book Governing Through Crime: How the War on Crime Transformed American Democracy and Created a Culture of Fear argues that the war on crime was associated with a general criminalization of social problems, which has led to a culture of fear and substantially increased intrusion of the government into people's lives. Similarly, Garland's (2001) book The Culture of Control: Crime and Social Order in Contemporary Society examines the rise of punitiveness in public sentiment and public policy in the aftermath of the Great Society's war on poverty.

\section{Politics, crime, and criminal justice}

As noted above, Piven and Cloward (2012) argued that rule-making is political. They also argue that rule breaking is political. Thus, it makes sense to consider politics in studies of rule breaking. Although few studies of crime (especially at the local level) have explicitly considered politics, Shihadeh and Flynn (1996) included a measure of Black political representation on city councils in relation to the size of the city's population in their study of the relationship between segregation and crime. In addition, Stucky (2003) included a variety of measures of institutional politics in his study of violent crime in 958 cities. He found both direct and interaction effects of city political system variables. Finally, Messner et al. (2008) included political measures in their examination of city-level robbery rates.

\footnotetext{
${ }^{1} \mathrm{I}$ am indebted to an anonymous reviewer for suggesting the value of mentioning the "mass reentry" issue.
} 
Macro-level theories of crime have also begun to explicitly consider politics. Social disorganization theory is one of the earliest sociological explanations for crime, and posits that breakdowns in neighborhood social control lead to crime. Although early theorizing focused on internal factors, theorists now acknowledge that factors outside the neighborhood can influence the ability of residents to organize to maintain social control. Bursik and Grasmick (1993) argue that neighborhoods do not exist in a vacuum and city governments may assist or fail to assist neighborhood organization for social control (see also Velez 2001). What Bursik and Grasmick call "public control" refers to the ability of neighborhoods to extract resources for services such as policing. Public control varies across neighborhoods (and Stucky 2003 argues city political systems) just as informal social control does. An interesting question for political sociologists would be to explore the conditions that affect how and when neighborhoods can extract resources to support informal social control to keep crime low.

A second major theory of crime to explicitly consider politics is Messner and Rosenfeld's (1997a) institutional anomie theory. Updating Merton's (1968) anomie theory, they note that the United States is characterized by a heavy emphasis on the economy over other institutions such as education, politics, and religion. This imbalance creates what they call "institutional anomie" which they argue leads to higher crime in the United States relative to other countries. Although this theory is still relatively new, there have been some studies testing propositions from it. In particular, cross-national studies have examined the link between inequality and homicide, noting that certain governments shield citizens from fluctuations in the economy more than others. Such programs reduce inequality, which has been shown to be associated with higher rates of violence (see Messner and Rosenfeld 1997b; Savolainen 2000). Additionally, Chamlin, and Cochran (1995) found that higher voter turnout reduced the link between poverty and property crime in states, and Maume and Lee (2003), using county level data, examined the links between voter turnout, education and welfare expenditures and homicide. Although there is still too little research on politics in crime theories to draw many conclusions, the inclusion of these concepts in theories and variables in research is exciting. Certainly, institutional anomie theory's focus on the balance of social institutions, should provide some interesting food for thought for political sociologists who so often focus on the relationship between the state, the economy and civil society.

There have also been several other criminological research questions that have highlighted the role of politics. For example, studies have examined how politics shapes policing expenditures and employment levels. This question offers a fertile research ground for testing various conceptions of the state. Some favor rational choice explanations, whereas others argue racial threat explanations (cf. Jackson 1986, 1989; Sever 2001, 2003; Stults and Baumer 2007). Additionally, Jacobs and Helms (1997) found that Republican political strength was associated with higher police employment at the national level, and Stucky (2005) found both direct and interaction effects of city political system variation on police employment across 945 cities in 1990. Studies have also considered the link between Hispanic or Black representation in city government and representation on police forces (see Alozie and Ramirez 1999, Kerr and Mladenka 1994). Finally, studies have also considered whether politics can help explain violence against police. For example, Jacobs and Carmichael (2002) argue that a more favorable political climate, as evidenced by the presence of a Black mayor, will reduce dissatisfaction with 
police and, as a result, reduce violence against police. Although there is some evidence to support this argument, disagreement still exists on the robustness of empirical support (cf. Jacobs 2010, and Kaminski and Stucky 2009, 2010). Each of these topics highlights a sub-national research area that could fruitfully be explored by political sociologists, who often focus on nation-states as the unit of analysis (Nash 2000).

\section{Hot topic: sex offender policies}

In this section, I discuss an increasingly studied criminological issue: sex offenses and offenders and highlight some research questions that might be explored by political sociologists. Public concern regarding sex crimes has been longstanding, as evidenced by legislative efforts to deal with so-called "sexual psychopaths" dating back to the 1930s (Sutherland 1950). Several highly publicized and brutal crimes against children, however, ratcheted up legislative activities starting in the late 1980s (see Hughes and Burchfield 2008). To combat the threat to public safety of those convicted of sex offenses, a variety of policies have been developed including sex offender registries (SORs) and community notification (CN) strategies (see Zevitz and Farkas 2000).

Such policies are designed to increase public awareness of those who have been convicted of a sex crime, or restrict the locations that registered sex offenders (RSOs) may live or go (see Hughes and Burchfield 2008) to reduce the likelihood that such offenders will successfully reoffend.

Public and legislative attention to the issue of policies regarding convicted sex offenders has corresponded to increased scholarly attention to these policies. Although studies have found that these policies can severely limit housing options for offenders (Levenson and Cotter 2005) and may concentrate offenders in areas of cities which may be least able to successfully integrate them (Hughes and Burchfield 2008), studies have not consistently shown that these policies are effective in reducing sex crime victimization (see Duwe and Donnay 2008; LeTourneau, Levenson, Bandyopadhyay, Armstrong, and Sinha 2010; Social and Stamatel 2010; Tewksbury and Jennings 2010; Tewksbury, Mustaine, and Stengel 2008; Vasquez, Maddan, and Walker 2008; Zgoba, Vehsey, and D’Alessandro 2010).

Though seemingly rational, RSO policies rest on several assumptions, regarding sex offenses and those who commit them, which may not be empirically sound (see Tewksbury and Levenson 2007). In fact, the term "sex offender" itself is potentially problematic because it lumps together potentially very disparate criminal behaviors and offenders under one umbrella. Note here the power of terms such as "sex offender." One assumption is that sex offenders present a great risk of re-offending. The lay public's image of those convicted of committing sex offenses presents them as individuals who repeatedly plan for and engage in sex crimes, and who are not amenable to rehabilitation (Sample and Bray 2003). Many studies suggest that sex offenders have relatively low rates of re-offending (e.g. Furby, Weinrott, and Blackshaw 1989; Sample and Bray 2003), and do not necessarily specialize in sex crimes (Miethe, Olson, and Mitchell 2006). A second core assumption underlying these policies is that strangers present the greatest threat. Research shows, however, that most sex crimes are committed by offenders who are known to the victim (often a family member) (Snyder 2000). Another assumption in these policies is that the risk of sex offenses is associated with registered sex offenders. Given the low rates of sex 
offender recidivism noted above, it seems likely that the majority of sex crimes are committed by offenders who are not RSOs.

Sex offender legislation provides an excellent example of a criminological research topic that can provide fertile research territory for political sociologists. Although research on this topic is relatively new, the questions that inhere within it are not to political sociologists. For example, sex offender laws are dramatically expanding despite severely limited evidence of their effectiveness and abundant evidence of their unintended negative consequences on RSOs and communities. Indeed, there are social movement organizations (SMOs) devoted to the repeal of sex offender legislation (Cromartin 2012), and of course, SMOs are a prominent research topic in political sociology. Yet, SMO's with a goal as politically unpopular as the repeal of RSO legislation might have very different dynamics, tactics, strategies, and prospects for success than SMO's with other goals. Exploring such differences across SMO's could be very enlightening. In addition, Sample, Evans, and Anderson (2010) argue that community notification laws are largely symbolic - meant to appease the public but not necessarily to change offender behavior. Symbolic politics is a core issue for political sociologists. Hence, the expertise a political sociologist could bring to bear on sex offender legislation is likely to be great. Indeed, Craun, Kernsmith, and Butler (2011) note that registries appear to be everywhere these days, expanding to gun offender and dangerous dog registries. A political sociologist might examine whether, how, and where these additional registries gain (or fail to gain) traction. And, of course, there are many other areas of criminology such as the death penalty, drug control, and gun control where elements of symbolic politics seem to be at work that could also be fruitfully explored by political sociologists.

One might argue that sex offender legislation is simply the latest incarnation of what some have called the "punitive turn.” But if so, one question a political sociologist might explore is how the current trend toward expansion of sex offender laws fits with prior chapters in the history of mass incarceration such as the war on drugs. It seems reasonable that a political sociologist might find some similarities between the war on drugs and the growth in RSO legislation, yet there are likely to be differences. For example, which theory of the state best explains the rise in sex offender legislation? Certainly the racial threat element of sex offender legislation is far less obvious than it is in the war on drugs.

Sex offender policies developed at the federal level have also created certain obligations for state and local governments, which face choices on how to implement them with limited resources. From a political sociological perspective, it would be interesting to examine which states comply or fail to comply with these federal regulations and why as a public policy issue. ${ }^{2}$

Comparative research in political sociology tends to be cross-national (Nash 2000). Although cross-national research is critically important, sex offender legislation provides an opportunity for political sociologists to move down a level of aggregation to compare states. Indeed one recent study noted that there is tremendous variation across states in sex offender legislation

${ }^{2}$ I am indebted to an anonymous reviewer for this point. 
(Mancini, Barnes, and Mears 2011). This allows political sociologists to explore how state to state political variation influences the development and form of these policies, as it surely must.

\section{A few additional areas of overlap between criminology and political sociology}

To this point, I have discussed criminological research likely to interest political sociologists. I conclude by discussing a few additional areas that highlight substantial overlaps between criminology and political sociology_research on protests, the "penal-welfare complex", and policing. Recall that Piven and Cloward (2012) point out that rule making and rule breaking are both inherently political. Although crime is one form of rule breaking, another is social protest. A large literature has developed in political sociology examining the link between protests and welfare expansion on the theory that welfare can be used by the state to reduce the public dissatisfaction that leads to protest (see Isaac and Kelly 1981; Piven and Cloward 1971). For example, a study by Fording (2001) considers the relationships among racial protests, welfare and criminal justice policies in testing "pluralist" and "social control" theories of the state. Fording (2001) concludes that social control theories of the state are generally more supported than pluralist theories. Perhaps the larger point is that there is substantial overlap in welfare and criminal justice, indeed some see them as the "carrot and the stick" and refer to this web of state agencies and policies as the penal-welfare complex (e.g. Beckett and Western 2001; Garland 1985; Haney 2004; Inverarity and Grattet 1989; Wacquant 2009).

One related question that has been examined by political sociologists and criminologists is the policing of protests. This topic involves core political sociological issues such as power, rule breaking, and the state. Earl (2011) provides an excellent overview of this issue from a political sociological point of view. For additional reading on the policing of riots from a criminological point of view, I would recommend a 2013 special issue of Policing and Society (volume 23, number 1) titled "Riots and Social Protest in an Age of Austerity".

Although necessarily brief, the overlaps noted here are not simply a convenient hook to suggest that political sociologists should expand their horizons. Such questions as what and how much the state should provide for its citizens are inextricably linked to other questions such as how should the state attempt to guarantee individual rights and maintain public order. Insofar as both political sociologists and criminologists study the power, and the nature, role, and functions of the state, each is limited when the disciplines ignore the other's research, methods, and insights.

\section{Conclusion}

My goal for this essay was to provide a brief look at some criminological research likely to be of interest to political sociologists. I began by highlighting some commonalities in the perspectives to the two disciplines, followed by a discussion of several criminological research areas that have touched on politics in hopes that political sociologists might become more aware of studies they might not otherwise have found. Then, I discussed a recent topic of great interest to criminologists — sex offender legislation — and noted some research questions political sociologists might explore. Finally, I discussed protest, the penal-welfare complex, and policing to highlight additional overlaps between criminology and political sociology. And in terms of 
future research overlap, no doubt criminologists and political sociologists would benefit from reading each other's work on immigration (e.g. Michalowski 2012 for a discussion of Arizona's controversial immigration law).

Reading research on familiar topics from the lens of other disciplines allows one to think of old problems in new ways or consider them with different methods, data, or theory. Power, politics, the nature and role of the state, and social control are all core issues for political sociologists and criminologists. So the fields can only be strengthened by increased awareness of each other's research. 


\section{References}

Alozie, Nicholas O., and Enrique J. Ramirez. 1999. A Piece of the Pie and More: Competition and Hispanic Employment on Urban Police Forces. Urban Affairs Review 34: 456-475.

Balfour, Gillian. 2006. "Re-imagining a Feminist Criminology.” Canadian Journal of Criminology and Criminal Justice 48:735-752.

Barker, Vanessa. 2009. The Politics of Imprisonment: How the Democratic Process Shapes the Way America Punishes Offenders. New York: Oxford University Press.

Beccaria, Cesare.1996 [1764]. Of Crimes and Punishments. Translated by Jane Grigson with an introduction by Marvin Wolfgang. New York: Marsilio Publishers.

Beckett, Katherine. 1997. Making Crime Pay: Law and Order in Contemporary American Politics. New York: Oxford University Press.

Beckett, Katherine and Theodore Sasson. 2000. The Politics of Injustice: Crime and Punishment in America. Thousand Oaks, CA: Pine Forge.

Beckett, Katherine and Bruce Western. 2001. "Governing Social Marginality: Welfare, Incarceration, and the Transformation of State Policy.” Punishment and Society 3: 43-59.

Blalock, Hubert. 1967. Toward a Theory of Minority-group Relations. New York: John Wiley.

Blauner, Robert. 1972. Racial Oppression in America. Harper and Row.

Bonacich, Edna. 1972. “A Theory of Ethnic Antagonism: The Split Labor Market.” American Sociological Review 37: 547-59.

Bursik Jr., Robert J. and Harold G. Grasmick. 1993. Neighborhoods and Crime: The Dimensions of Effective Community Control. New York: Lexington Books.

Campbell, Michael C. 2011. "Politics, Prisons, and Law Enforcement: An Examination of the Emergence of “Law and Order” Politics in Texas?” Law and Society Review 45:631-665

Chambliss, William. 1999. Power, Politics, and Crime. Westview Press.

Chamlin, Mitchell B., and John K. Cochran. 1995. “Assessing Messner and Rosenfeld’s Institutional Anomie Theory: A Partial Test.” Criminology 33: 411-429.

Chiricos, Theodore G., and Miriam A. Delone. 1992. Labor Surplus and Punishment: A Review and Assessment of Theory and Evidence. Social Problems 39: 421-446. 
Clarke, Ronald and Derek Cornish. 1985. "Modeling Offenders Decisions: A Framework for Research and Policy.” Crime and Justice 6: 147-185.

Craun, Sarah W., Poco D. Kernsmith, and N.K. Butler. 2011. "Anything that can be a Danger to the Public”: Desire to Extend Registries Beyond Sex Offenses.” Criminal Justice Policy Review 22:375-391.

Cromartin, Erin. 2012. "Collective Action for the Rights of Sex Offenders: Evaluating Social Movement Organizations.” Wayne State University Dissertations. Paper 535.

http://digitalcommons.wayne.edu/oa_dissertations/535. Accessed 5 October 2012.

D’Alessio, Stewart J., and Lisa Stolzenberg. 2003. "Race and the Probability of Arrest.” Social Forces 81: 1381-1397.

Daly, Kathleen, and Meda Chesney-Lind. 1988. “Feminism and Criminology.” Justice Quarterly 5: 497-538.

Dobratz, Betty A., Lisa K. Waldner, and Timothy Buzzell. 2012. Power, Politics, and Society: An Introduction to Political Sociology. Boston, MA: Allyn \& Bacon.

Duwe, Grant, and William Donnay. 2008. “The Impact of Megan’s Law on Sex Offender Recidivism: The Minnesota Experience.” Criminology 46: 411-446.

Earl, Jennifer. 2011. "Political Repression” Iron Fists, Velvet Gloves, and Diffuse Control.” Annual Review of Sociology 37:261-284.

Eitle, David, Stewart J. D’Alessio, and Lisa Stolzenberg. 2002. "Racial Threat and Social Control: A Test of the Political, Economic, and Threat of Black Crime Hypotheses.” Social Forces 81: 557-576.

Evans, Peter, Dietrich Rueschemeyer, and Theda Skocpol. 1984. Bringing the State Back In. New York: Cambridge University Press.

Faulks, Keith. 2000. Political Sociology: A Critical Introduction. New York: New York University Press.

Fording, Richard C. 2001. "The Political Response to Black Insurgency: A Critical Test of Competing Theories of the State.” American Political Science Review 95: 115-130.

Furby, Lita, Mark R. Weinrott, and Lyn Blackshaw. 1989. "Sex Offender Recidivism: A Review.” Psychological Bulletin 105: 3-30.

Garland, David. 1985. Punishment and Welfare: A History of Penal Strategies. Brookfield, VT: Gower Publishing. 
Garland, David. 1990. Punishment and Modern Society. Chicago, IL: University of Chicago Press.

Garland, David. 2001. The Culture of Control: Crime and Social Order in Contemporary Society. Oxford: Oxford University Press.

Gottschalk, Marie. 2006. The Prison and the Gallows: The Politics of Mass Incarceration in America. New York: Cambridge University Press.

Hagan, John. A. R. Gillis, and John Simpson. 1990. "Clarifying and Extending Power-Control Theory.” American Journal of Sociology 95:1024-37.

Hagan, John, A. R. Gillis, and John Simpson. 1985. "The Class Structure of Gender and Delinquency: Toward a Power-Control Theory of Common Delinquent Behavior.” American Journal of Sociology 90:1151-1178.

Haney, Lynne A. 2004. “Introduction: Gender, Welfare, and States of Punishment.” Social Politics 11:333-362.

Hicks, Alexander and Joya Misra. 1993. "Political Resources and the Growth of Welfare in Affluent Capitalist Democracies, 1960-1982.” American Journal of Sociology 99: 668-710.

Horowitz, Donald L. 1985. Ethnic Groups in Conflict. Berkeley, CA: University of California: Berkeley Press.

Hughes, Lorie. A., and Keri B. Burchfield. 2008. "Sex Offender Residence Restrictions in Chicago: An Environmental Injustice?” Justice Quarterly 25: 645-671.

Inverarity, James and Ryken Grattet. 1989. "Institutional Responses to Unemployment: A Comparison of U.S. Trends, 1948-1985." Contemporary Crises 13: 351-370.

Isaac, Larry and William R. Kelly. 1981. "Racial Insurgency, the State, and Welfare Expansion: Local and National Level Evidence from the Postwar United States." American Journal of Sociology 86: 1348-1386.

Jackson, Pamela I. 1986. "Black Visibility, City Size, and Social Control.” Sociological Quarterly, 27: 185-203.

Jackson, Pamela I. 1989. Minority Group Threat, Crime, and Policing: Social Context and Social Control. New York: Praeger.

Jacobs, David and Jason T. Carmichael. 2002. "Subordination and Violence Against State Control Agents: Testing Political Explanations for Lethal Assaults Against the Police.” Social Forces 80: 1223-1251. 
Jacobs, David and Ronald E. Helms. 1997. “Testing Coercive Explanations for Order: The Determinants of Law Enforcement Strength Over Time.” Social Forces 75: 1361-92.

Jacobs, David. 2010. “The Influence of Black Mayors on Police Officers Killed: A Comment on Kaminski and Stucky.” Homicide Studies 14:193-201.

Kaminski, Robert J., and Thomas D. Stucky. 2009. "Reassessing Political Explanations for Murders of Police.” Homicide Studies 13:3-20.

Kaminski, Robert J., and Thomas D. Stucky. 2010. "Further Tests of the Influence of Black Mayors on Murders of Police: A Response to Jacobs.” Homicide Studies 14:202-212.

Kerr, Brinck and Kenneth R. Mladenka. 1994. "Does Politics Matter? A Time-Series Analysis of Minority Employment Patterns.” American Journal of Political Science 38: 918-943.

Kubrin, Charis E., Thomas D. Stucky, and Marvin D. Krohn. 2009. Testing Theories of Crime and Deviance. Oxford University Press.

LeTourneau, Elizabeth J., Jill S. Levenson, Dipankar Bandyopadhyay, Kevin S. Armstrong, and Debajyoti Sinha. 2010. "Effects of South Carolina's Sex Offender Registration and Notification Policy on Deterrence of Adult Sex Crimes.” Criminal Justice and Behavior 37: 537-552.

Levenson, Jill S., and Leo P. Cotter. 2005. “The Impact of Sex Offender Residence Restrictions: 1,000 Feet from Danger or One Step from Absurd?” International Journal of Offender Therapy and Comparative Criminology 49: 168-178.

Levitt, Steven D. 1997. "Using Electoral Cycles in Police Hiring to Estimate the Effect of Police on Crime.” American Economic Review 87: 270 - 90.

Liska, Allen E. 1992. Social Threat and Social Control. Albany, NY: State University of New York Press.

Mancini, Christina, J. C. Barnes and Daniel P. Mears. 2011. “It Varies from State to State: An Examination of Sex Crime Laws Nationally” published online 10 October 2011. Criminal Justice Policy Review Accessed 5 October 2012 at http://cjp.sagepub.com/content/early/2011/09/30/0887403411424079.

Maume, Michael O. and Matthew R. Lee. 2003. "Social Institutions and Violence: A SubNational Test of Institutional Anomie Theory.” Criminology 41: 1137-1172.

Merton, Robert K. 1968. Social Theory and Social Structure. The Free Press, a Division of Simon and Schuster. 
Messner, Steven F., Glenn D. Deane, Thomas D. Stucky, Charis E. Kubrin, and Kelly McGeever. 2008. Not 'Islands, Entire of Themselves': Exploring the Spatial Context of CityLevel Robbery Rates. Journal of Quantitative Criminology 24:363-380.

Messner, Steven F., and Richard Rosenfeld. 1997a. Crime and the American Dream, $2^{\text {nd }}$ ed. Belmont, CA: Wadsworth.

Messner, Steven F., and Richard Rosenfeld. 1997b. "Political Restraint of the Market and Levels of Criminal Homicide: A Cross-national Application of Institutional-Anomie Theory.” Social Forces 75: 1393-1416.

Michalowski, Raymond. 2012. "Ethnic Cleansing American Style: SB1070, Nativism, and the Contradictions of Neo-liberal Globalization. Journal of Criminal Justice, Available online December 24, 2012.

Miethe, Terance. D., Jodi Olson, and Ojmarrh Mitchell. 2006. "Specialization and Persistence in the Arrest Histories of Sex Offenders: A Comparative Analysis of Alternative Measures and Offense Types.” Journal of Research in Crime and Delinquency 43: 204-229.

Miller, Lisa L. 2008. The Perils of Federalism: Race, Poverty, and the Politics of Crime Control. Oxford: Oxford University Press.

Nagin, Daniel S. 1998. "Criminal Deterrence Research at the Outset of the Twenty-First Century.” Crime and Justice 23: 1-42.

Nash, Kate. 2000. Contemporary Political Sociology: Globalization, Politics, and Power. Malden, MA: Blackwell Publishing.

Neuman, W. Lawrence. 2005. Power, State, and Society: An Introduction to Political Sociology. Boston, MA: McGraw-Hill.

Olzak, Susan. 1990. "The Political Context of Competition: Lynching and Urban Racial Violence, 1882- 1914." Social Forces 69: 395-421.

Olzak, Susan. 1992. The Dynamics of Ethnic Competition and Conflict. Stanford University Press.

Ousey, Graham C, and Matthew R. Lee. 2008. "Racial Disparity in Formal Social Control: An Investigation of Alternative Explanations of Arrest Rate Inequality." Journal of Research in Crime and Delinquency 45:322-355.

Parker, Karen F. 2008. Unequal Crime Decline: Theorizing Race, Urban Inequality, and Criminal Violence. New York: New York University Press. 
Parker, Karen F., Brian J. Stults, and Stephen K. Rice. 2005. "Racial Threat, Concentrated Disadvantage and Social Control: Considering the Macro-Level Sources of Variation in Arrests.” Criminology 43: 1111-1134.

Piven, Frances Fox, and Richard A. Cloward. 1971. Regulating the Poor: The Functions of Public Welfare. New York: Vintage.

Piven, Frances Fox, and Richard A. Cloward. 2012. "Rule Making, Rule Breaking, and Power." In The Handbook of Political Sociology: States, Civil Societies, and Globalization, Janoski, Thomas, Robert Alford, Alexander Hicks, and Mildred A. Schwartz (editors). Cambridge University Press. http://www.credoreference.com/book/cuppolsoc, Accessed 5 October 2012.

Quinney, Richard. 1977. Class, State, and Crime. New York: Longman.

Rusche, Georg, and Otto Kirschheimer. [1939] 1968. Punishment and Social Structure. New York, NY: Russell and Russell.

Sample, Lisa. L., and Timothy M. Bray. 2003. “Are Sex Offenders Dangerous?” Criminology and Public Policy 3: 59-82.

Sample, Lisa. L., Mary K. Evans, and Amy L. Anderson. 2011. "Sex Offender Community Notification Laws: Are their Effects Symbolic or Instrumental in Nature.” Criminal Justice Policy Review 22: 27-49.

Savolainen, Jukka. 2000. "Inequality, Welfare State, and Homicide: Further Support for the Institutional Anomie Theory.” Criminology 38: 1021-1043.

Schoenfeld, Heather. 2010. "Mass Incarceration and the Paradox of Prison Conditions Litigation.” Law \& Society Review 44:731-768.

Sever, Brion. 2003. “The Minority Population/ Police Strength Relationship: Exploring Past Research.” Criminal Justice Studies 16: 153-171.

Sever, Brion. 2001. “The Relationship Between Minority Populations and Police Force Strength: Expanding Our Knowledge.” Police Quarterly 4: 28-68.

Shihadeh, Edward S., and Nicole Flynn. 1996. "Segregation and Crime: The Effects of Social Isolation on the Rates of Black Urban Violence.” Social Forces 74: 325-352.

Simon, Jonathan. 2007. Governing Through Crime: How the War on Crime Transformed American Democracy and Created a Culture of Fear. Oxford: Oxford University Press.

Sims-Blackwell, Brenda. 2000. "Perceived Sanction Threats, Gender, and Crime: A Test and Elaboration of Power-Control Theory.” Criminology 38:439-488. 
Snyder, Howard N. 2000. Sexual Assault of Young Children as Reported to Law Enforcement: Victim, Incident, and Offender Characteristics. Washington, DC: U.S. GPO, Bureau of Justice Statistics, NCJ182990. , http://www.ojp.usdoj.gov/bjs/pub/pdf/saycrle.pdf.

Socia, Kelly M., and Janet P. Stamatel. 2010. "Assumptions and Evidence Behind Sex Offender Laws: Registration, Community Notification, and Residence Restrictions.” Sociology Compass 4: $1-20$.

Spitzer, Steven. 1975. “Toward a Marxian Theory of Deviance.” Social Problems 22: 638-651.

Stucky, Thomas D. 2003. "Local Politics and Violent Crime in U.S. Cities.” Criminology 41: 1101-1136.

Stucky, Thomas D. 2005. “Local Politics and Police Strength.” Justice Quarterly 22: 139-169.

Stucky, Thomas D., Karen Heimer, and Joseph B. Lang. 2005. "Partisan Politics, Electoral Competition, and Imprisonment: An Analysis of States over Time.” Criminology 43: 211-248.

Stucky, Thomas D., Karen Heimer, and Joseph B. Lang. 2007. “A Bigger Piece of the Pie? An Analysis of State Corrections Spending Over Time.” Journal of Research in Crime and Delinquency 44: 91-123.

Stults, Brian J., and Eric P. Baumer. 2007. "Racial Context and Police Force Size: Evaluating the Empirical Validity of the Minority Threat Perspective.” American Journal of Sociology 113:507546.

Sutherland, Edwin. H. 1950. "The Sexual Psychopath Laws. Journal of Criminal Law and Criminology 40: 543-554.

Tewksbury, Richard, and Jennings, Wesley. G. 2010. "Assessing the Impact of Sex Offender Registration and Community Notification on Sex-Offending Trajectories." Criminal Justice and Behavior 37: 570-582.

Tewksbury, Richard, and Jill Levenson. 2007. "When Evidence is Ignored: Residential Restrictions for Sex Offenders.” Corrections Today 69: 54-57.

Tewksbury, Richard., Elizabeth E. Mustaine, and Kenneth M. Stengel. 2008. "Examining Rates of Sexual Offenses from a Routine Activities Perspective.” Victims and Offenders 3: 75-85.

Turk, Austin. 1969. Criminality and Legal Order. Chicago, Ill: Rand McNally.

Vasquez, Bob E., Sean Maddan, and Jeffrey T. Walker. 2008. "The Influence of Sex Offender Registration and Notification Laws in The United States: A Time-Series Analysis.” Crime and Delinquency 54: 175-192. 
Velez, Maria B. 2001. “The Role of Public Social Control in Urban Neighborhoods: A MultiLevel Analysis of Victimization Risk.” Criminology 39: 837-863.

Wacquant, Loic. 2009. Punishing the Poor: The Neo-Liberal Government of Insecurity. Durham, N.C.: Duke University Press.

Zevitz, Richard G., and Mary Ann Farkas. 2000. Sex offender community notification: Managing high-risk criminals or exacting future vengeance. Behavioral Sciences and the Law 18: 375-391.

Zgoba Kristen, Bonita M. Vehsey, and Melissa Dalessandro. 2010. “An Analysis of the Effectiveness of Community Notification and Registration: Do the Best Intentions Predict the Best Practices.” Justice Quarterly 27: 667-691. 